\title{
6
}

\section{ELT MATERIALS FOR BASIC EDUCATION IN BRAZIL: IS THERE ROOM FOR AN ELF-AWARE PRACTICE?}

\author{
MATERIAIS DE ENSINO DE INGLÊS PARA A EDUCAÇÃO \\ BÁSICA BRASILEIRA: HÁ ESPAÇO PARA UMA PRÁTICA \\ SENSÍVEL AO INGLÊS COMO LÍNGUA FRANCA?
}

\author{
Sávio Siqueira ${ }^{1}$ \\ Universidade Federal da Bahia, Brazil
}

\begin{abstract}
It is a fact that ELT practices around the world have historically been ENL-oriented and inner-circle emulating. It is also a fact that such status quo has been overtly challenged in many contexts. Despite signs of resistance and the chronic lack of dialogue between Academia and school realities, it is plausible to say that ELF and its research findings are slowly gaining ground in regular ELT classrooms, especially due to the inclusion of ELF-related issues in teacher education programs, both at pre-service and in-service levels. This article is based on a brief study conducted in a pre-service teacher education program at Bahia Federal University (UFBA), Salvador, Brazil, whose objective was to analyze how a few English textbooks approved by the National Textbook Program (Programa Nacional do Livro Didático) for local public high schools are linguistically, methodologically, and ideologically conceived, and to what extent their activities were adaptable to an alternative ELF-aware orientation. It then aims to share and discuss some of the results of the referred study, including examples of activities, assuming that an ELF-aware pedagogy in EFL-oriented contexts is perfectly viable, even when departing from pre-existing materials which already take into consideration features of the local reality and how English can be realistically used by these specific speakers.
\end{abstract}

Keywords: ELF; ELF-aware pedagogy; Basic Education; local materials; Brazil.

1 savio_siqueira@hotmail.com 
Resumo: É fato que práticas de Ensino de Língua Inglesa (ELI) em todo o mundo têm historicamente se pautado por premissas do Inglês como Língua Nativa (ILN) e pelo mimetismo de aspectos relacionaados aos países do Círculo Interno. É fato também que tal status quo tem sido abertamente desafiado em muitos contextos. Apesar de sinais de resistência e a falta de dialógo crônica entre a Academia e a realidade escolar, pode-se afirmar que o ILF, assim como os seus achados de pesquisa, está aos poucos ganhando terreno em salas de aula de inglês, em especial por conta da inclusão de tópicos relacionados ao tema, em cursos de formação docente, tanto inicial quanto continuada. Este artigo é baseado em um breve estudo conduzido em um programa de formação de professores da UFBA, Salvador, Brasil, cujo objetivo foi analisar como alguns livros didáticos para o Ensino Médio aprovados no PNLD são linguística, metodológica e ideologicamente concebidos, e até que ponto suas atividades poderiam seguir uma orientação para o ILF. Assim, o artigo expõe e discute alguns resultados, além de incluir exemplos de atividades presentes nos materiais, ponderando que uma pedagogia voltada para o ILF em contextos maracadamente aconrados no ILE (Inglês como Língua Estrangeira) é perfeitamente viável, mesmo quando se parte de materiais didáticos existentes que já levam em consideração aspectos da realidade local e como o inglês pode ser usado de forma mais realística por esses falantes específicos.

Palavras-chave: ILF; pedagogia sensível ao ILF; Educação Básica; materiais locais; Brasil.

The language I speak

Becomes mine,

its distortions, its queernesses

All mine, mine alone.

KAMALA DAS (1934-2009)

\section{INTRODUCTION}

This article is the outcome of an intellectual exercise specially conceived for the ELF11 Conference (London) in the colloquium entitled New Trajectories in Teacher Education: ELF awareness and pedagogical implications in ELT classrooms, having as conveners Roma Tre University's ELF scholars Enrico Grazzi and Lucilla Lopriore. Anchored in two guiding open questions, What are the pedagogical implications of ELF as regards the future of ELT? and Can ELF awareness be enhanced within the educational context in your country? How?, participants were invited to reflect over the questions, focusing on different ELF-related subareas at will. As one of my main interests within ELT has always been materials critical analysis and production, and also for having engaged in a similar discussion for a recent publication (SIQUEIRA; MATOS, 2019), I then opted to follow that track, concentrating specifically on textbook series written for Basic Education (High 
School) $)^{2}$ in Brazil, led by the theoretical assumption that at the point we currently are in ELF-research findings and developments, there should be room for an ELFaware practice in such contexts, departing from pre-existing instructional resources.

After around two decades of solid, diverse, and intense research work and reflection over results, we have reached a point in ELF studies that more and more attention is to be devoted to the pedagogical implications and implementations of its findings. As Jenkins (2015) has proposed, we are to be living an ELF3 stage $^{3}$ in which multilingualism plays a crucial role, and the emergence of concepts like translanguaging (GARCÍA; WEI, 2014), translingual practices, translocal spaces of communication, global contact zones (CANAGARAJAH, 2013), fluid trans-semiotic systems (SIFAKIS, 2017), linguistic and semiotic repertoires (GARCÍA; WEI 2014; SIFAKIS 2017), spatial multilingual repertoires (PENNYCOOK; OTSUJI, 2014; JENKINS 2015), mobile resources (BLOOMAERT, 2010), among others, have come to the forefront of research agendas. In other words, the implications of all sorts are surely to grow exponentially.

Bearing in mind the notion of 'ELF-awareness,' as proposed by Sifakis and Bayyurt (2018, p. 459), that is, "the process of engaging with ELF research and developing one's own understanding of the ways in which it can be integrated into one's classroom context," my reflection here will draw on the Brazilian reality ${ }^{4}$, with an emphasis on a possible ELF-aware practice in ELT classes departing from locally-produced materials. As Lopriore and Vettorel (2015) advocate, in the plurality of contexts where English is being used and taught, more and more we will need to consider approaches based on awareness-raising

2 High School in Brazil's Basic Education system is called “Ensino Médio," and comprises the three last years of that process. Upon completing this phase, students are entitled for higher education.

3 According to Jenkins (2015), ELF1 was the phase in which the earliest ELF research focused mainly on forms, although from the very start, accommodative processes were also identified as key factors in ELF communication. Concerning ELF2, as increasing amounts of empirical data were made available through different corpora (VOICE, ELFA, etc.), attention was turned to the diversity, fluidity, and variability revealed in the new data. The research focus then switched to a view of ELF as social practice. As she poses, "this meant exploring the functions fulfilled by the forms, the underlying processes they reveal" (p. 50), and thus the ways in which they "foster understanding of 'what is going on' in the interaction among speakers from different language backgrounds" (SEIDLHOFER, 2009, p. 56 as cited in JENKINS, 2015, p. 50).

4 Despite the fact that English is taught in different contexts in Brazil, especially in private language institutes, which comprise a huge industry in the country, the targeted reality, as mentioned, is the High School years. 
activities implemented through an ELF-oriented curriculum. While this does not fully happen, as we still have a long path to tread in that process, assessing and adapting the content in pre-existing ELT coursebooks and materials are a good way to start. That is what I propose to do here, taking as a parameter locally produced materials. But before we move on, let us get a bit familiar with the ELT reality in Brazil.

\section{THE ELT PICTURE IN BRAZIL}

Without a shade of a doubt, Brazil and South America are one of the most promising and desired markets by the global ELT industry. As a country from the so-called 'expanding circle' (KACHRU, 1985), English is taught and spoken as a foreign language (EFL), and fully taken as a cultural product of great value. According to Rajagopalan (2003, p. 92), "the overwhelming presence of English in Brazil is no news to anyone who has even a nodding acquaintance with the country and its recent history." For the Indian-Brazilian scholar, "over the past several years, the English language has been making steady inroads into the nation's cultural scenario, dominating practically all walks of life and making its presence felt in every nook and corner of the country" (p. 92).

But despite this massive presence of the language in the country which, in many ways, has caused its 'commodification' (JORDÃO, 2004), the access to English in Brazil is far from being democratized. In other words, in spite of different policies and initiatives to stimulate and create opportunities for students to learn, not only English but foreign languages in general in regular schools, this objective as a whole has not so far reached greater levels of success.

A report released by the British Council in São Paulo in 2014 has shown that only $5.1 \%$ of the Brazilian population aged over 16 has some knowledge of the English language. Figures of that work revealed that there are important differences between generations, and just as an example of this disparity, among younger people aged 18-24, for instance, the percentage of those stating they speak English just doubles, reaching meager 10\%. This picture shows that, in spite of the condtion of English as a lingua franca around the globe, in terms of English (and foreign language) education, Brazil is still very far from a democratization of the access to additional languages, especially when we consider the underprivileged classes, overtly the great majority of the Brazilian population (COGO; SIQUEIRA, 2017). 
This not so optimistic reality has in many ways impregnated the Brazilian society along the years with a strong belief that learning a foreign language in regular schools is a very challenging, if not impossible, endeavor ${ }^{5}$. As the official educational system (both public and private) has proved incapable of offering quality FL courses and programs, compensatory education, that is, language institutes or the so-called "free courses," has promptly flourished with the objective of readily responding to a huge demand in an increasingly profitable market.

Notably, the aforementioned segment has long fed upon the idea that languages like English, for instance, are a crucial asset to guarantee the access to better personal and professional opportunities in today's globalized world. Once it "is all over the place - on neon signs, shop windows, television commercials, popular magazines and newspapers, and even in T-shirts worn by ordinary people, including many who speak little or no English" (RAJAGOPALAN, 2003, p. 92), the global language is taken and sold as a very valuable cultural merchandise throughout the entire country.

The perfect illustration of this disturbing discrepancy in FL education in Brazil is the case of the myriad of the aforementioned private language institutes which have proliferated at an enormous pace, advertising and selling foreign languages, especially English, as a powerful and attractive product, even when they are commercialized at the most utilitarian level. In other words, the failure of one segment (public) has meant the success of another (private). And this is especially true in Brazil and in several other countries in South America, as Bohn (2003, p. 160) would remind us:

Since neither the private nor the public school systems in Brazil offer adequate English education in the regular elementary and secondary curriculum, wealthier families send their children to special private language courses where they can develop the necessary linguistic skills for immediate academic as well future professional needs.

It is rather difficult to arrive at an exact number of language institutes in Brazil, but figures reveal that the number of franchise language schools in the country "has increased from 20 companies with around 2,600 units in 1997 to 36 companies comprising over 5,000 units (DINIZ DE FIGUEIREDO, 2017, p. 2).

See Lima (2011) for a broader discussion on the issue, including how English can be successfully taught and learned in regular schools in Brazil, especially in the public sector. 
According to the same author, the sector's earnings grew about $16 \%$ in 2012/13, showing that "while the very right to study English had been denied in regular schooling, members of the higher socioeconomic classes have continuously invested in learning the language" (Ibid, p. 2).

As a regular discipline, English is part of all curricula at different levels, including in its more instrumental modality, English for Specific Purposes (ESP), and the development of reading skills, both in regular mandatory education (middle and high school) and diverse university programs. In those contexts where English is broadly thought to be taught and learned successfully, that is, language schools and free courses, the ELT industry exercises a very strong influence in local institutional policies which basically respond to the demands of an elite who is deeply affiliated to an enduring EFL tradition.

The global demand for English has numerous implications for ELT, and no matter through which lenses we see and approach this expansion, the fact is that "ELT practices that have for long been in place need to be reviewed drastically with a view to addressing the new set of challenges being thrown at us by [the phenomenon]" (RAJAGOPALAN, 2004, p. 113). Criticism towards the Anglocentric positioning of much ELT is nothing recent. As English plays this crucial role of connecting people from very different linguacultural backgrounds, routinely (re)constructed in intercultural interactions, it is about time we go for a "dynamic and fluid approach that recognizes the nature of intercultural communication, particularly in [lingua franca] scenarios, as well as the situated, emergent relationship between language and culture" (HOLMES; DERVIN, 2016, p. 17-18).

Although such aspects are fairly well-understood by teachers and teacher educators in Brazil, the EFL traditional orientation still seems to prevail, endorsing classroom practices that usually take place disconnected from social, historical, cultural, and political issues, normally enrooted in tenets of nativespeakerism. In other words, despite the fact that the celebrated globality of English and its consequent de-nationalization have "[called] into question the linguistic and pragmatic norms of English that have traditionally been taken for granted and conceptually pluralize [its] forms and uses" (KUBOTA, 2015, p. 23), significant changes in ELT in the country are still to completely reach practitioners, as they inevitably are to start moving into what Fay, Sifakis and Lytra (2016) would call a 'post-native modeled TEFL era'. In that direction, Dewey and Patsko (2018) highlight the relevance of ELF in current language 
teacher education, suggesting a more plurilingual methodological approach to incorporating ELF in teacher development initiatives.

\section{THE NATIONAL CURRICULAR BASIS AND THE TB PROGRAM}

In the last few years, basic compulsory education in Brazil has been going through several changes, involving decisions that in the area of modern foreign languages have resulted in heated controversies and unquestionable setbacks. Most recently, within the scope of a not well-received national reform, the Ministry of Education has made English the only obligatory FL discipline throughout basic education, demoting, for instance, Spanish, which, after great efforts of the entire academic community, had earlier conquered the right to be taught at both primary and secondary stages along with English ${ }^{6}$. At the birth of the Common National Curricular Basis (CNCB), all foreign languages had their status demoted to 'optional,' regardless of the region where schools are located, and whether the presence and circulation of English is more or less important (COGO; SIQUEIRA, 2017).

Despite its polemic conception and developments, the Brazilian CNCB, implemented in 2018, has admittedly advanced in the proposal for teaching English. To start, EFL is to be replaced by ELF as an overall orientation ${ }^{7}$. In this sense, the CNCB legitimizes English not as the language spoken in the Inner Circle, but as an opportunity of access to the globalized world, and thus for learners to exercise their citizenship and broaden the possibilities of interaction in practically all contexts around the planet (BRASIL, 2018).

6 The Law 11.161/2005 determined that Spanish was to be taught optionally to the Lower Secondary Level (Ensino Fundamental II), and mandatorily for the Upper Secondary Level (Ensino Médio). With the promulgation of the Law 13.415/2017, which introduced the Common National Curricular Basis (Base Nacional Curricular Comum - BNCC), encompassing, among other things, a Reform of the Upper Secondary Level (Ensino Médio), the former law was revoked and English became the sole language to be learned throughout Brazil's basic education system. Spanish can still be offered at the Upper Secondary Level, but only as an option, which was seen by the academic community as a significant backlash for FL education in the country, that is, the reinforcement of the hegemony of English, and the consolidation of public policies still rooted within the tenets of monolingualism.

7 See Duboc (2019) for a critical analysis of the issue. Under a Bakhtinian perspective, she points out the existence of an epistemological conflict in the whole conception of the CNCB due to the fact that when it comes to practice, ELF's fluidic, hybrid and situated nature is contradicted by orientations and contents founded in normativity, consensus and standardization. 
With that in mind, the Curricular Basis assumes that teaching English under a lingua franca perspective brings about three important implications: revising the relationship between language, territory and culture, once the largest number of English speakers are non-native, expanding the view of multiliteracies, especially those from the digital world in which practices approximate, and enabling different semiotic processes and languages (verbal, visual, corporal, and audiovisual). The CNCB also makes it clear that when it comes to teaching approaches, as already mentioned, several traditional beliefs and assumptions are to be relativized (BRASIL, 2018).

It is equally important to mention that the Basis is founded in some organizing axes, being the "intercultural dimension" one of crucial importance for the whole ELF concept ${ }^{8}$. According to the document, this axis originates from the comprehension that "cultures, especially in the contemporary society, are in a constant process of interaction and (re)construction" (BRASIL, 2018, p. 245). In this sense, "the treatment of English as a lingua franca imposes challenges and new priorities to teaching, among which are the increase of reflections about the relations between language, identity, and culture, and the development of [students'] intercultural competence" ${ }^{\prime \prime 9}$ (Ibid, p. 245).

Within this scenario, the National Textbook Program (NTP) ${ }^{10}$ is a very important public policy, and despite the fact that it was implemented with a different name in the early decades of the 20th century, foreign languages (English and Spanish) were included in the program only in 2011. In fact, it is one the oldest governmental programs in the country, and in almost 80 years of existence it has received different names and gone through several reforms.

In a nutshell, the NTP encompasses basic education (total of 12 years) and its main objective is to support teachers' pedagogic work through the free distribution of print-based courseware to learners matriculated in these contexts of the public school system. After a meticulous analysis and then the approval of a number of coursebooks, the Ministry of Education issues a "Guide to Coursebooks" with reviews of the selected collections. This Guide is then sent to schools all over the country, and based on the information contained in the

8 The other ones are "Speaking," "Reading," “Writing," and "Linguistic knowledge."

9 Original in Portuguese: Nesse sentido, o tratamento do inglês como língua franca impõe desafios e novas prioridades para o ensino, entre os quais o adensamento das reflexões sobre as relações entre língua, identidade e cultura, e o desenvolvimento da competência cultural.

10 In Portuguese, Programa Nacional do Livro Didático (PNLD). 
document, teachers, and possibly other professionals related to each discipline, choose the collection that best suits their political pedagogical project (PPP $)^{11}$.

The whole evaluation process takes place nationally at an average of three years, and then the approved textbooks are to be freely distributed to different sectors within the educational structure. Concerning FL, covering only lower and upper secondary grades (Fundamental II and Ensino Médio), once collections are chosen locally, they are sent to schools, used by students, but according to official policy, they should be well-kept, so at the end of the year, they are to be returned for re-use by students of the subsequent years. Besides textbooks, the program also includes the distribution of dictionaries (SIQUEIRA; MATOS, 2019).

It is from that universe that come the specific textbooks which served as the source of the aforementioned brief investigation. As stated, the goal of the study was to analyze how these coursebooks are linguistically, methodologically, and ideologically conceived, and discuss if there is room (or not) for an ELFaware practice. Besides that, it was my intention to check if these books can be aligned to the tenets of the brand-new Common National Curricular Basis which, as we have seen, theoretically, embraces ELF and an ELF-aware pedagogy as innovations to take place in the country's regular schools from now on.

\section{ELT COURSEBOOKS MADE IN BRAZIL: A STUDY12}

Research on ELT textbooks has continuously revealed that a significant number of these materials tends to emphasize pre-established and norm-biased representations of language (GRAY, 2002; LOPRIORE; VETTOREL, 2015; SIQUEIRA, 2015, etc.). They normally present hegemonic varieties and their stereotypical cultural aspects as the sole valid exemplifications of the English language, ignoring the fact that English, for quite a significant time already, has increasingly been used by non-native speakers who, as we know, "are actively reinterpreting, reshaping and redefining [it] in oral and written form" (NAULT, 2006, p. 316). Such approach has, in many ways, "contributed to the promotion of a simplified monolithic view of the English language (...), and it does not

11 Every school in Brazil is expected to have a PPP. The PPP defines a school's identity and sets goals to provide quality education to the community. It is taken as 'political' because it sees schools as spaces for the formation of critical and responsible citizens who are expected to act both individually and collectively in society.

12 This section was partially adapted from Siqueira and Matos (2019). 
adequately prepare learners for the dynamic variety and plurality they will meet as English users" (LOPRIORE; VETTOREL, 2015, p. 13).

As we know, this is the prevailing panorama in most Expanding Circle contexts, including Brazil (TÍLIO, 2006; TÍLIO; ROCHA, 2009; SIQUEIRA, 2015). Even so, it is always important to remember that alternative approaches might always emerge and provoke possible changes, even if they take place in a slow and subtle manner. Since the ELT collections approved by Brazil's Ministry of Education as part of the NTP have to go through an extensive and highly competitive screening process, this has aroused interest in knowing to what extent locally produced textbooks would reinforce the norm-biased premises or would at least try to break up with the tradition. As local materials guided by documents that require content appropriate to the local contexts are a reality in Brazil, such orientation, in my view, would be the logical path to follow.

This brief evaluation of three coursebooks approved by the 2015 NTP focused on how such materials are linguistically, methodologically, and ideologically oriented ${ }^{13}$, and if they integrate any references, either implicit or explicit, to ELF. Based on the results, it was posed a discussion on how it might be possible to depart from pre-existing standard content and potentially promote a pedagogy in the EFL classroom that is sensitive to ELF premises. The materials (textbook series) analyzed, and previously explored more extensively in Siqueira and Matos (2019), were Alive High (MENEZES, V. ET. AL., 2013) (henceforth TBS1), Way to Go! (TAVARES, K.; FRANCO, C., 2013) (henceforth TBS2), and High Up (DIAS, R.; JUCÁ, L.; FARIA, R., 2013) (henceforth TBS3) ${ }^{14}$. Each set of books comprises 3 volumes of 8 units each (See Appendix).

\section{Category 1: Linguistic orientation (LO)}

Concerning the first category of analysis, linguistic orientation, which is basically presented in the Teacher's Book as part of the philosophy of the material, TBS1 supports the idea of language as a complex semiotic system, and as such, alive, dynamic, and capable of constant evolution and change. It sees English as an instrument of access to information, social groups and cultures from different parts of the world, and invites students to recognize different linguistic variations. Although not openly stated, the uses of English of the

13 Following this general objective, each point was taken as a category for the analysis process.

14 The coursebooks were selected at random, basically due to availability to the volumes and access to publishers' local representatives. 
collection, almost by default, apply to American Standard (AmE), and no references or mentions to ELF were identified.

TBS2 adopts a Bakhtinian dialogic perspective of language in which language is taken as a concrete reality and not a scientific abstraction. Just like TBS1, TBS2 conceives English as an important tool for the access to diverse information, social groups and cultures of different countries - therefore, to various ways of thinking, feeling, and acting in the world. It also regards to the importance of English in the representation of cultural and linguistic diversity. Although authors defend that students are to be exposed to speakers of English from different nationalities, as in TBS1, the default English of the collection is AmE. Just like the previous material, no references or mentions to ELF were identified.

Anchored in a socio-interactional approach, TBS3 sees language as a social action that takes places within and through the relationship with the other. It incorporates the notion of multimodality as one of the crucial aspects of language in the current digital era. The material highlights the conception of the educational aspect of learning English, therefore putting emphasis on the development of a sense of citizenship. No references or mentions to ELF were found, and despite the presence of a few activities which consider the variability of English, once again, the default English is still AmE.

\section{Category 2: Methodological orientation (MO)}

Concerning the second category, methodological orientation, apart from minor differences, the three series affiliate with a communicative approach to teaching English, predominantly founded in textual genres (articles, interviews, e-mail messages, book excerpts, movie reviews, comic strips, among others), always in a contextualized way, and integrating skills (reading, speaking, listening and writing) with strong reference to information and communication technologies. More specifically, TBS1 adopts a perspective that sees language learning not just as a means of communication, but also of reflection towards action in society. TBS2 emphasizes its alignment to a Vygotskian socio-historical and cultural perspective, in which the roles of teachers and students reject teacher-centered pedagogical practices and the sole transmission of information and knowledge. It also integrates the notion of multiliteracies, and the same goes for TBS3 that is equally based on a socio-interactional view of learning, and reveals its affiliation to a FL pedagogy oriented by the development of critical, 
digital, and multimodal literacies. Although not overtly stating its connection with an ELF-oriented perspective, it is possible to assume that several of the features described as ground to the collections' methodological orientations favor the integration with ELF-aware practices, once "ELF's natural habitat is the different multilingual and multicultural settings, [and], as a highly malleable means of communication, [ELF] is appropriated by its users to adapt to the linguistic, pragmatic and cultural elements for each individual interaction" (SIFAKIS; TSANTILA, 2019, p. 2).

\section{Category 3: Ideological orientation (IO)}

Despite some positive features mentioned above, as for the third category, ideological orientation, none of the three collections openly discusses political and ideological implications of teaching and learning a global language like English nowadays and its role as a global lingua franca. Due to the absence of this aspect, it is possible to infer that these coursebooks, although bringing interesting and meaningful topics for the local context (See Figure 1), offering learners a broader and more critical view of the world, still respond to a protocol that does not take advantage of findings, reflections, and advances already made public by ELF research. A clear example of this posture is the central role attributed to the NS model throughout the materials, leading us into re-affirming that "despite a growing tendency to include non-native speakers (NNSs) as characters [in ELT materials], they are not overtly presented as 'legitimate users of English'" (LOPRIORE; VETTOREL, 2015, p. 15).

However, as we are to see later in the text, the collections do approach issues within an ideological frame, especially when authors choose to bring about topics that question certain consolidated premises and practices, thus stimulating students' critical thinking. This can be illustrated, for instance, by discussions on standard/non-standard dialects, linguistic prejudice, cultural stereotypes, or the use of African post-colonial literary texts. Although not stated explicitly, no one can deny that the choices of topics and how they are set to be approached follow the ideological orientation of the writers of the materials. We also know that sometimes authors' ideological perspectives do clash with those of editors and publishers, which, sometimes because of the commercial appeal, may end up producing very bland and soulless materials. 


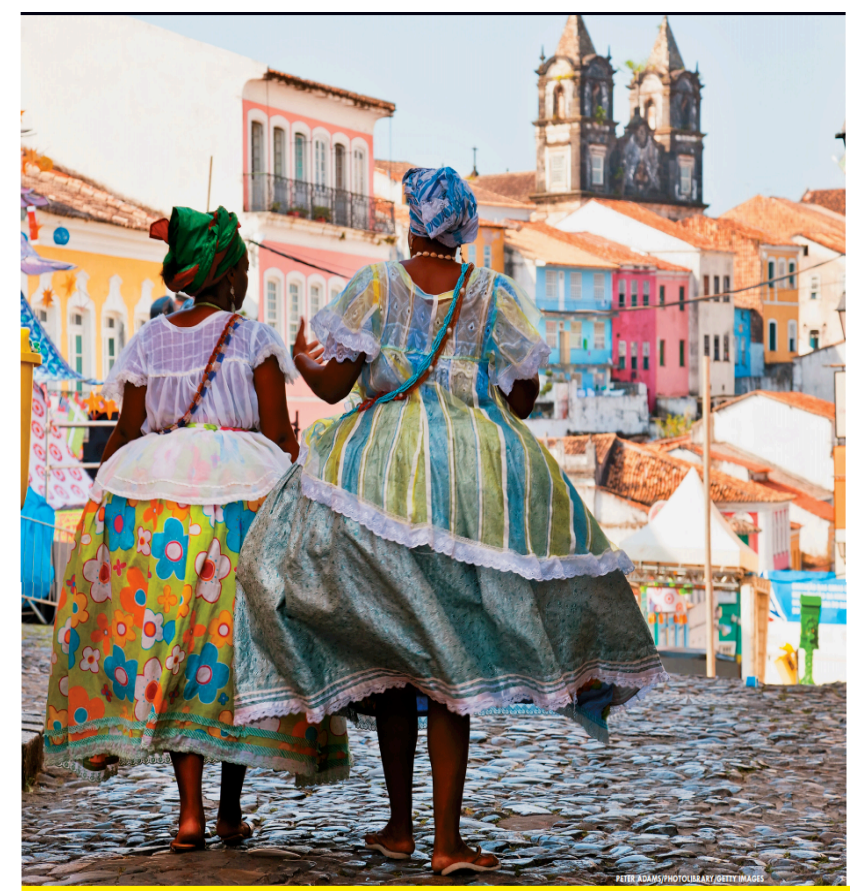

\section{BRALLL: OUR PEOPLE, OUdi BOULITily}

Figure 1: High Up 1, p. $26^{15}$

(Originally in Portuguese) In this unit you will: -reflect about some stereotypes attributed to Brazilians

-learn words related to Brazilian habits and food

-work with the genres "lists" and "interviews" -use the simple past

-identify and use adverbs of frequency

Needless to say that the presence of these materials produced in Brazil and written by experienced Brazilian ELT professionals is an important step for the local teaching and learning communities. Locally produced teaching materials can be as good as (or even better than) socially anaesthetized international materials that are usually designed for a depersonalized and general global audience (AKBARI, 2008).

This brief analysis has shown that we still have a long way to go concerning informed changes that are to reach ELT classrooms around the globe. With Englishes emerging in every corner of the world, and the language functioning mainly as a lingua franca in intercultural encounters, materials

15 This illustration and a couple others from the book High Up were officially authorized for reproduction by the publisher, Macmillan Brasil. 
cannot continue to be conceived and commercialized based solely on ENL norms, cultures, and communication styles. More and more, such a practice has become incompatible with the reality of those individuals who use English to communicate internationally ${ }^{16}$.

Despite the panorama described above, and knowing that textbooks are not organized and produced under an ELF-sensitive perspective, teachers can critically use these resources to work towards the development of their students' awareness of ELF and of what it might imply for the process of learning English today. In the collections analyzed, for instance, this is possible through a broader exploration of activities related to themes that they already bring like "the English language in the world," "appreciation of local knowledge," and "global representations". TBS2 and TBS3, although in a timid way, integrate prompts for debates about the global spread of English.

These discussions can naturally be expanded and approached under an ELF-sensitive approach, calling attention to the type of interactions that are to take place in different contexts, plus presenting and reinforcing the nature of ELF as a flexible, co-constructed, and variable means of communication (COGO, 2015). Even in an EFL context, activities adopting this orientation depart from the premise that English is not a product that belongs only to hegemonic Inner Circle countries. Once this happens, teachers can take opportunities to emphasize the global expansion of English and debate over who its current speakers are and their status with relevance to the NS, today, a minority group of English users. If an activity already integrates oral segments of supposedly NNS of English, as it is timidly the case in the three Brazilian series, the teacher can bring to the discussion implications for a language that has more non-native than native users. Besides, it is possible to raise questions about how this situation changes communication in this language, if students used English the same way or if they would still try to imitate a hegemonic NS model.

Unquestionably, teacher education is to play a crucial role as to equip practitioners with the overall knowledge towards becoming aware of ELF and the associated implications for classroom practice (DEWEY; PATSKO, 2018; GIMENEZ; EL KADRI; CALVO, 2018). In other words, we have reached a point that

[it] is essential to design ELF-aware teacher education programmes based not only on theoretical but also on practical training, where teachers engage

16 For a broad discussion on how to design or adapt ELF-aware teaching materials, see Guerra and Cavalheiro (2019). 
in a process of continuous critical reflection on ELF in both theory and practice and devise their own ways of integrating ELF into their teaching practices (KEMALOGLU-ER; BAYYURT, 2019, p. 160).

Although the focus of most activities in the coursebooks is not on the development of a possible ELF-awareness, the teacher can use these pre-existing sources to create new activities which may stimulate learners to debate issues related to language variation, accent, intelligibility, just to mention a few. For example, under the previously cited topic, "the English language in the world", TBS1 brings a sequence of activities that discusses issues like language variation and linguistic prejudice. Departing from literary fragments, a series of exercises in the book depicts colloquial language samples used by a character in the short story “The Verger," by Irish-descent novelist Somerset Maugham (1874-1965), and by Eliza Doolittle, the famous character from My Fair Lady (p. 91-95). A short section entitled "Language variation" (p. 94), where examples of non-standard English taken from both fragments are quoted and analyzed, calls learners' attention to that specific aspect. Following this, the exercise brings the lyrics to the song Wouldn't it be loverly?, sided by a small glossary and a movie poster of My Fair Lady. A final section called "Beyond the lines" prompts students to work on questions like "Who determines which dialect will be considered standard in a country?"; "Why should we learn standard dialects?"; "Have you ever seen any case of linguistic prejudice?" (p. 95). Pursuing similar objectives, using literature as a point of departure, TBS3 brings a couple of texts by African writer Wole Soyinka. Activities like these, explicitly ELF-prone, can easily be expanded by an ELF-aware teacher not only to stimulate students to debate the topics, but also to make explicit ELF's adaptive moves and pragmatic strategies used by speakers in their rich intercultural interactions.

Working on the assumption of "appreciation of local knowledge," further interesting possibilities of expanding classroom work towards an ELF-sensitive perspective are found, for instance, in TBS3. The first unit of Volume 1, whose title is "English Everywhere" (see Figures 2 and 3), is illustrated by a picture of a Portuguese/English sign on a Brazilian beach saying "Aluga/To Hire" (p. 10), resembling a sort of translingual practice (CANAGARAJAH, 2013; GARCÍA; WEI, 2014) where the two languages interact and visibly occupy the same place of importance, prompting the use of strategies employed by ELF speakers to communicate successfully. 
In the sequence, the unit opener brings a picture of a kangaroo and one of the famous soldiers who guard the Queen's Buckingham Palace in London, leading the reader into thinking of countries like Australia and England (p. 11). Along with these, come the following questions in L1 (Portuguese): "To what extent is English present in Brazil?"; "Are scenes like the ones depicted common where you live?"; "Which aspects of the countries where English is spoken are represented in the illustrations?" Potentially, the authors could illustrate the activity with cultural aspects of non-hegemonic English-speaking countries, but an ELF-aware teacher can easily cross that bridge and do that.

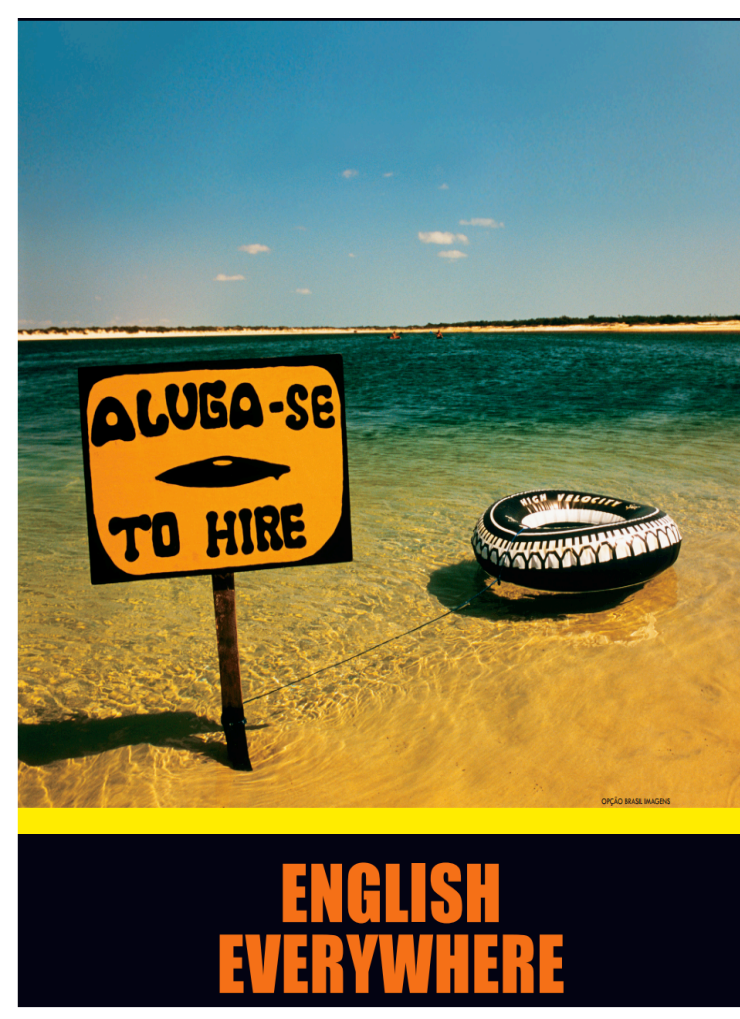

Figure 2, High $U p$ 1, p. 10

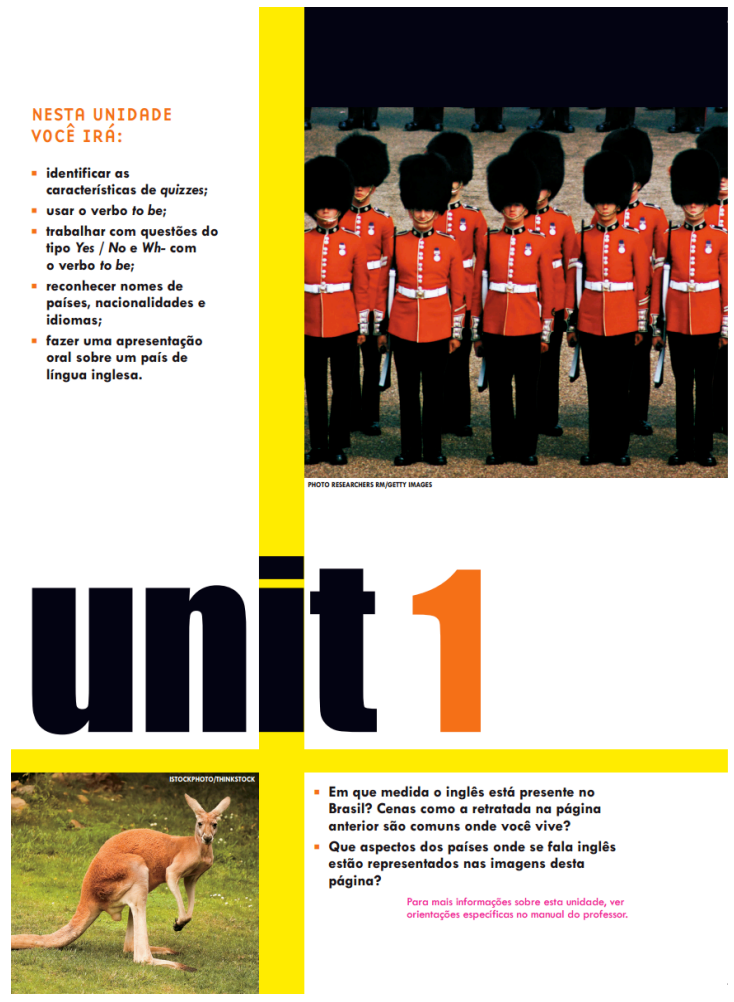

Figure 3: High Up 1, p. 11

In another activity, TBS3 brings an illustration of a supposed Brazilian street with stores and a food kiosk bearing signs such as Tob's, Drive Thru, Hot Dog, Pet Shop, Lan House, Wi-fi, and Happy Hour (see Figure 4). 
3 Look at this scene from a Brazilian city and discuss with a classmate. Which of these English words do you see around your neighborhood? Are they common? Respostas pessoais.

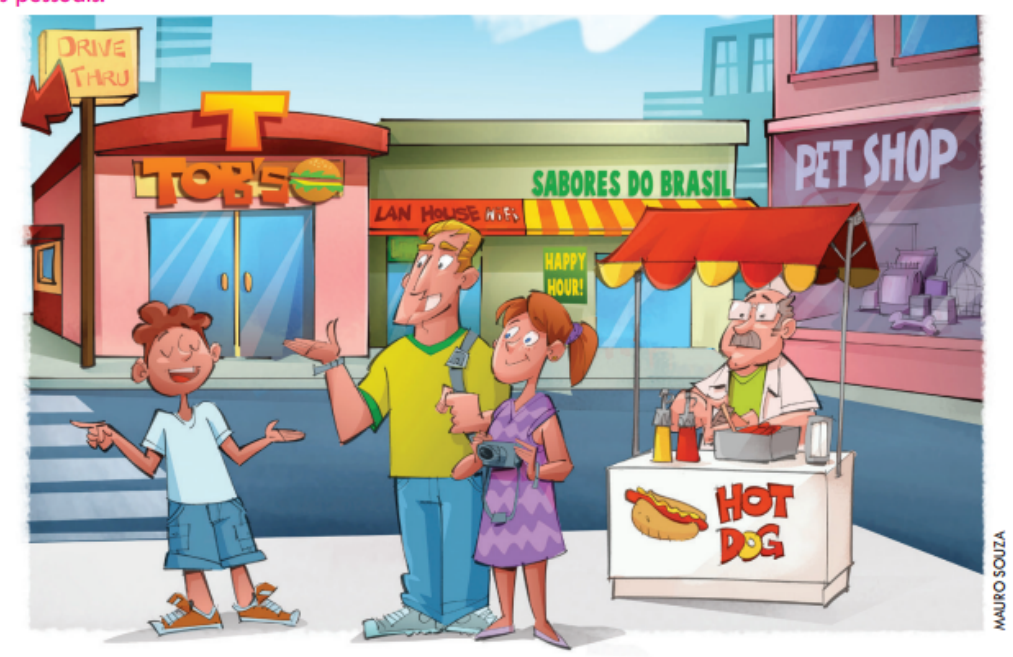

Make a list of English words or expressions we use in Brazil. Write them under the appropriate category.

\section{Glothing}

Food Sports

Figure 4: High Up 1, p. 13
Technology

Learners are asked to identify such words and expressions, state whether they are familiar with them or not, and if they find them where they live. They are also asked to list English words or expressions we use in Brazil in categories like clothes, food, technology, sports, leisure, etc. After this, the following questions are to be approached: "Why is the English language so important in the contemporary world?"; "Do you remember a situation when you had to speak English? If so, describe it," and "How does the English language help you in your daily life?".

Activities like this stimulate the discussion about the real use of the TL in the learner's local context, and the teacher can easily expand the debate adding, for instance, other materials from real-life (GUERRA; CAVALHEIRO, 2019), and questions like: "When you used English in a given situation what difficulties did you face and how did you overcome them?"; "Did you speak English to a native or non-native user?"; "Did you notice any difference in the way he/she speaks English?"; "Have you ever talked to any foreigner using your native language?"; "If so, could you notice any strategy (adaptation, use of gestures, accommodation, code-switching, translanguaging, etc.) this person used in order to facilitate the communication between you two?"; "Do you usually try to do 
something similar when you speak English with anybody, native or nonnative?", and so forth.

Working on such comparisons, trying to include and stimulate experiential learning as much as possible, students can have the opportunity to engage in activities that will certainly create an atmosphere of intersecting between an initially EFL-based class and an expansion that can potentially lead into the understanding of the nature of ELF communication. Consequently, this will serve as a preparation for learners to step beyond those common and consolidated traditional ELT expectations and confront the two orientations:

The EFL orientation to language teaching is one which has historically been monolingual and Western-looking, with the language models and cultures of Western countries seen as the ideal targets learners should aspire to. [...] The ELF orientation to language teaching turns this on its head, requiring both learners and teachers of English to start thinking about English in a new way: as a global communication tool which can be used to facilitate interaction between people from a wide variety of national and linguistic backgrounds (KICZKOWIAK; LOWE, 2018, p. 23).

Another example of this appreciation for local knowledge and production that can evoke ELF lies, in our specific case, in the different forms of representation of Brazil and Brazilians through images, texts, and audio/video segments. This appreciation of the local as the basis for English learning helps students internalize the idea that once we acquire a new language, it does become part of our linguacultural repertoire. Thus, we can and should struggle to appropriate it in order to communicate in different situations, including, and mainly, when it comes to introducing and discussing aspects and elements of our own culture (NAULT, 2006). For instance, in TBS2 (Volume 3, p. 15-28), there is an entire unit about "Ethnic diversity in Brazil." TBS3 (Volume 1, p. 28) brings an activity where students are to read and analyze several statements about Brazil, and say if they "agree" or "disagree," justifying their answers. The purpose of the latter activity is to discuss stereotypes departing from issues local students are potentially very familiar with. In other words, beginning from the known to reach the unknown. In this very unit of TBS3 (Volume 1, p. 26-41), the linguistic content is introduced through texts and activities that refer to different cities/states in the country.

As mentioned, through activities that privilege local knowledge and individual experience, the teacher can integrate other similar initiatives that stimulate learners to reflect over the aspect of the English language as belonging 
to them, with its diverse facets and possibilities. Therefore, he/she can make it clear to students that they need to know how to use the language not to simply talk about the other and their culture(s) (as still happens in most EFL classrooms around the world), but also, and, especially, to talk about themselves, their own culture(s), their needs, interests, and singularities (SIQUEIRA, 2012; DINIZ DE FIGUEIREDO; SANFELICI, 2017). This posture is to be considered a very significant change, and an ELF orientation is an open field for this to happen.

Already present in the collections, transnational representations are also of great importance for an ELT practice that seeks to encourage and strengthen an ELF conception. Once learners hold on to an appreciation of the local in order to guarantee their empowerment through the access to English, they also need to be aware that the great majority of users today are likely to communicate with people from many different nationalities and cultures. So, it is crucial to keep in mind the importance of developing an openness to diversity, and a predisposition against judgmental attitudes and any kind of prejudice.

In spite of bringing many representations of English hegemonic societies like the US and UK, the Brazilian materials referred to do not fail entirely in including representations of other English-speaking and non-English-speaking countries. TBS1, for example, brings a unit about "dance," and learners are introduced to dance representations from different countries, such as a Turkish folk dance, a famous Brazilian dancer named Carlinhos de Jesus, a dance festival in Italy, Brazilian indigenous dance rituals in the state of Mato Grosso, and ballet dancers in New York (Volume 1, p. 50).

In a grammar activity on “Women's Marathon," TBS2 (Volume 2, p. 57) depicts important global runners like Merry Lepper (US), Tegla Loroupe (Kenya), and Paula Radcliffe (UK). On page 58 of the same volume, there is a similar exercise on Brazilian gold medalist and Paralympic athlete Daniel Dias. It also brings a whole unit on cultural diffusion and cultural diversity, contrasting Brazil with countries like India, for example (p. 15-28).

TBS3 brings activities with representations of global celebrities like Penélope Cruz (Spain), Cristiano Ronaldo (Portugal) (Volume 1, p. 22), J. K. Rowling (UK), Andrea Bocelli, (Italy), Charlize Theron (South Africa), footballer Lionel Messi (Argentina) (p. 44), among others. On pages 68-69 of the same book, there is an interesting reading activity on "Teens who are changing the world". In Volume 2, there is a unit on "Hip Hop culture \& music" (p. 64-79), which discusses the movement from different perspectives, bringing information about 
artists like Jay-Z (US), Lurdez da Luz (Brazil), and Shahin Najafi (Iran) (Figure 5).

2 Read the following biographical facts about two artists.

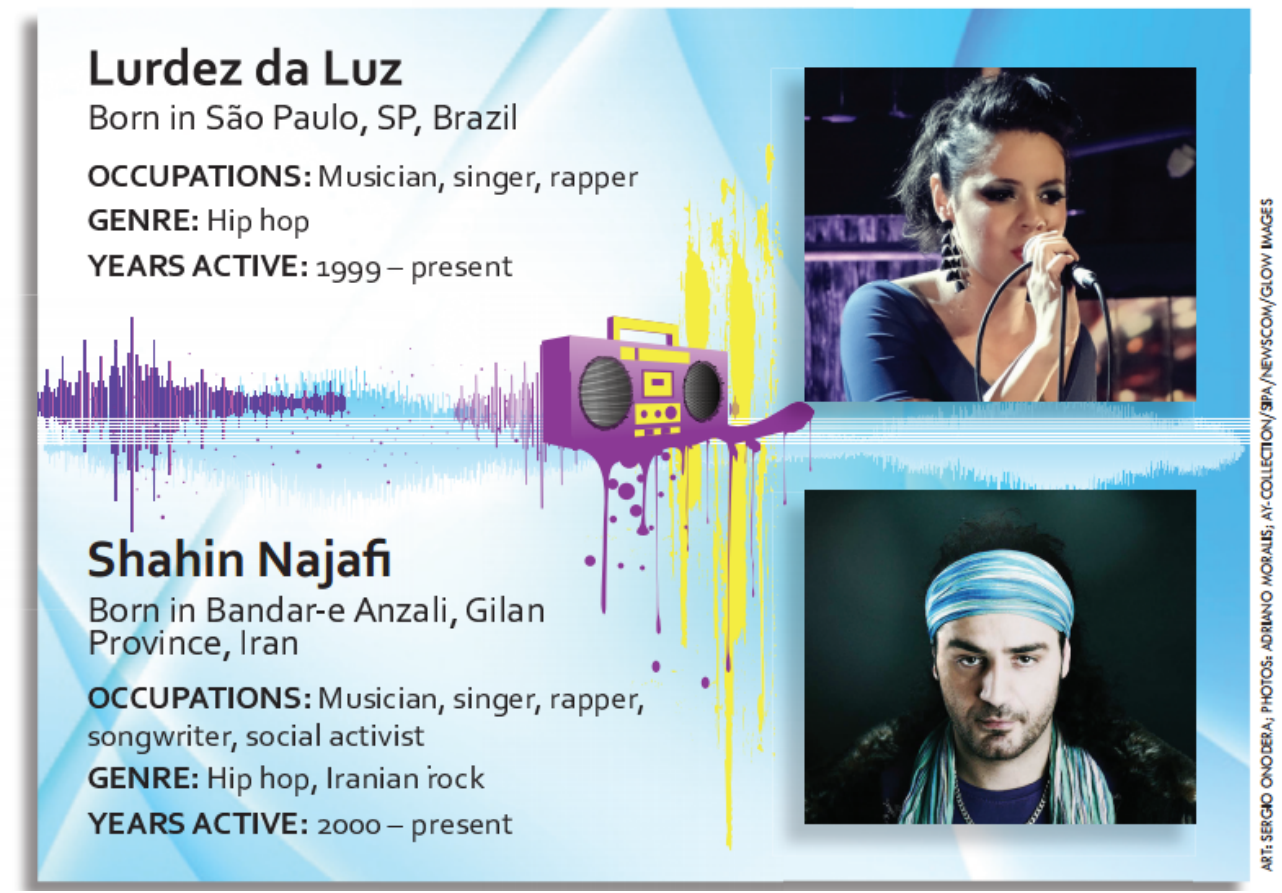

Figure 5: High Up 2, p. 69

These and many other examples are found throughout the materials, and with the analysis, it was possible to see an attempt of not concentrating heavily on representations of a single country or society. In fact, this variety of representations can be used by teachers to create, adapt or expand activities, stimulating, among other things, the development of their learners' intercultural competence, a very important feature highly needed for successful ELF interactions in today's world.

\section{CONCLUDING REMARKS}

From what I have tried to discuss in the article, it can be concluded that the time for an ELF-aware practice has arrived. Drawing on a brief study of a few Brazilian-produced EFL coursebooks, I contended that ELF-aware materials do have a place in the current ELT classroom, and even when textbooks are not conceived under an ELF orientation, adaptations in their contents can stimulate 
teachers and students to bring about this discussion and turn it into common practice. In fact, while overall ELF research findings are still distant from the practice of the regular teacher, he/she can identify in the materials available the resources he/she can use in order to turn these into ELF-aware activities or critically discuss some aspect(s) indirectly approached by the original materials. In other words, despite the gap that still exists (and that needs urgently to be closed) between ELF research developments and everyday classroom practice (DEWEY; PATSKO, 2018), the teacher can search within the materials he/she has at hand alternative ways of activating them, inserting ELF features they might have access to in their praxis and showing to learners that what the book brings is not the only possibility of seeing and understanding English.

I would like to proceed towards to conclusion of the paper referring back to the two questions posed in the original colloquium mentioned at the beginning of the article. As for Question 1, What are the pedagogical implications of ELF as regards the future of ELT?, I believe several implications of ELF are already in course in ELT like the decentering of the native speaker or a closer attention to pragmatic strategies in negotiated meaning-making practices. But as we firmly enter an ELF3 phase, more attention is to be given to the multilingual learner and the resources he/she uses to communicate. This will imply a shift to a poststructuralist paradigm (CANAGARAJAH, 2018) where, among other aspects, transgression (PENNYCOOK, 2006) and post-normativity (DEWEY, 2012) will inform our decisions. Models of reference are to be expanded, programs and curricula are to be redesigned in light of new categories such as situatedness, negotiation, co-construction, adaptation, emergence, etc. (DUBOC, 2018). Besides, teacher education, materials, and assessment systems are to be decolonized in order to respond to this new reality, deposing especially the "monolingual utopia" which, in many contexts, Brazil included, is still well and strong, and potentially "serve as starting points for a critical intervention towards transformation" (DUBOC, 2018, p. 175).

Concerning Question 2, Can ELF awareness be enhanced within the educational context in your country? How? I am sure it can, beginning especially with the introduction of the whole issue in pre-service teacher education and, naturally, in continuous in-service programs. When it comes specifically to materials design, as discussed and presented along the text, we can see that, due to national curricular guidelines, local textbooks, although not conceived under an ELF-orientation, do bring many activities and exercises that, in comparison to 
international materials, provide more meaningful opportunities for leaners to be engage in ELF interactions. We could see that learners can use English to talk about themselves (once they see themselves represented in the material), realize that English is not the language of only hegemonic inner-circle countries like the US and Britain, and explore and use English in different ways in their own realities.

All in all, I do believe that ELF-aware materials, as posed by Guerra and Cavalheiro (2019), can potentially foster and mirror more realistic practices based on ELF features like intelligibility, pluricentricity, variation, locality, hybridity, accommodation, difference, just to name a few. They can deconstruct monolithic and ethnocentric orientations, they can bring to class meaningful communicative situations other than those romantic, trivial ones we are so much used to seeing, and in, a broader sense, they can surely help develop what Duboc (2018, p. 175) calls a "curricular attitude in place of any fixed and normative set of curricular guidelines." More still, they can motivate teachers to exercise their agency to work in between the cracks of the curriculum, so that any "discursive practices in textbooks, course plans, lesson plans, school procedures, students' and teachers' ways of being, seeing, and acting might serve as starting points for a critical intervention towards transformation" (DUBOC, 2018, p. 175). In other words, ELF-sensitive materials hold a great potential to lead people into teaching and learning English with an attitude.

The few examples taken from these local ELT materials are merely a sample of what can be done to break with an ELT tradition that has prevailed along the years, and certainly needs urgent adjustments. As Sifakis (2014, p. 320) points out, "studies of the changing nature of English language communication at a time when non-native speakers are rapidly increasing and the communication contexts multiply on a global scale frequently make reference to implications for the ESOL classroom." One way to start and soon consolidate this 'revolution' is through existing materials, keeping in mind that teachers will surely need to be aware of these advances, and through critical analyses of the materials that they use, possibly find different resources and ways of inserting ELF in their classrooms on a daily basis. This may go on until the time when these adaptations will no longer be necessary.

All in all, and alluding to Kamala Das' call when she declares that the "language [we] speak is [ours], its distortions and its queernesses, all [ours], [ours] alone," when the ELT industry is finally compelled to rethink its 
commercial protocols and opt for privileging content that indeed reflects the real world, ELF will be there at the first hour. After all, it is ELF, not English per se, that really connects people from all walks of life in the most diverse intercultural encounters nowadays.

So, as Jordão and Marques (2018, p. 58) would argue, "learning and teaching English from an ELF perspective means we switch focus from institutionalized grammar rules to the encouragement of negotiation from diverse grammars and linguacultural collections that emerge from each and every communicative encounter in English." In their view, "[our] classrooms must [...] be filled with as many possibilities of encounters, with as many meaning-making situations in English as possible" (Ibidem, p. 58). With that in mind, continue the authors, "only that way we can start to grasp the potential of multiplicity and intelligibility through negotiation in English, particularly if we highlight the contingency of communication among identities in a transnational perspective" (Ibidem, p. 58).

The ELT business world knows this, for sure. It is just a matter of time for these issues, flowing through the alluded cracks and fissures, to gain ground and expand, finally decolonizing ELT and provoking in all senses a rethinking and reshaping of its traditional pillars and orientations.

\section{REFERENCES}

AKBARI, R. Transforming lives: introducing critical pedagogy into ELT classrooms. ELT Journal, v. 62, n. 3, p. 276-283, 2008.

BLOMMAERT, J. The sociolinguistics of globalization. New York: Cambridge University Press, 2010.

BOHN, H. The educational role and status of English in Brazil. World Englishes, v. 22, n. 2, p. 149-172, 2003.

BRASIL. Base Nacional Comum Curricular (BNCC). Educação é a Base. Brasília, DF: MEC/CONSED/UNDIME, 2018. Available at: $<$ http://basenacionalcomum.mec.gov.br/images/BNCC_EI_EF_110518_versaofinal_site. pdf>. Access: Apr 26, 2019.

CANAGARAJAH, S. Translingual practice: Global Englishes and cosmopolitan relations. London/New York: Routledge, 2013. 
CANAGARAJAH, S. Translingual practice as spatial repertoires: Expanding the paradigm beyond structuralist orientations. Applied Linguistics, v. 39, n. 1, p. 31-54, 2018.

COGO, A. English as a lingua franca: Descriptions, domains and applications. In COGO, A.; BOWLES, H. (Ed.). International Perspectives on English as a Lingua Franca: Pedagogical Insights. New York: Palgrave Macmillan, 2015. p. 1-12.

COGO, A.; SIQUEIRA, S. "Emancipating myself, the students and the language": Brazilian teachers' attitudes towards ELF and the diversity of English. Englishes in Practice, v. 4, n. 3, p. 50-78, 2017.

DAS, K. An Introduction. In SOUZA, E. de. (Ed.). Nine Indian Women Poets. New Delhi: Oxford University Press, 1997. p. 95-96.

DEWEY, M. Towards a post-normative approach: Learning the pedagogy of ELF. Journal of English as a Lingua Franca, v. 1, n. 1, p. 141-170, 2012.

DEWEY, M.; PATSKO, L. ELF and teacher education. In JENKINS, J.; BAKER, W.; DEWEY, M. (Ed.). The Routledge Handbook of English as a Lingua Franca. Abingdon, UK/New York: Routledge, 2018. p. 441-455.

DIAS, R.; JUCÁ, L.; FARIA, R. High Up, São Paulo: Macmillan, 2013.

DINIZ DE FIGUEIREDO, E. H. Conceptualizations of English in the discourses of Brazilian language teachers: Issues of mobility, empowerment and international ownership. English Today, v. 33, n. 2, p. 1-7, 2017.

DINIZ DE FIGUEIREDO, E. H.; SANFELICI, A. M. Addressing culture from an EIL perspective in a teacher education course in Brazil. In MATSUDA, A. (Ed.). Preparing teachers to teach English as an international language. Bristol, UK: Multilingual Matters, 2017. p. 147-156.

DUBOC, A. P. M. Frankly speaking: Reading the concept of "English as a lingua franca" within the National Core Curriculum in light of Bakhtinian thought. Revista da ANPOLL, v. 1, n. 48, p. 10-22, Jan./Jun 2019.

DUBOC, A. P. M. The ELF teacher education: Contributions from postmodern studies. In GIMENEZ, T.; EL KADRI, M. S.; CALVO, L. C. S. (Ed.). English as a Lingua Franca in teacher education: A Brazilian perspective. Berlin: De Gruyter Mouton, 2018. p. 159-187.

FAY, R.; SIFAKIS, N. C.; LYTRA, V. Interculturalities of English as a Lingua Franca: International communication and multicultural awareness in the Greek context. In HOLMES, P.; DERVIN, F. (Ed.). The cultural and intercultural dimensions of English as a Lingua Franca. Bristol, UK: Multilingual Matters, 2016. p. 50-69. 
GARCÍA, O.; WEI, L. Translanguaging: Language, Bilingualism and Education. New York: Palgrave Macmillan, 2014.

GIMENEZ, T.; EL KADRI, M. S.; CALVO, L. C. S. Awareness raising about English as a lingua franca in two Brazilian teacher education programs. In GIMENEZ, T.; EL KADRI, M. S.; CALVO, L. C. S. (Ed.). English as a lingua franca in teacher education - A Brazilian perspective. Berlin: De Gruyter Mouton, 2018. p. 211-230.

GRAY, J. The global coursebook in English Language Teaching. In BLOCK, D.; CAMERON, D. (Ed.). Globalization and language teaching. London/New York: Routledge, 2002. p. 151-167.

GUERRA, L.; CAVALHEIRO, L. When the textbook is not enough: How to shape an ELF classroom? In: In: SIFAKIS, N. C.; TSANTILA, N. (Ed.). English as a lingua franca for EFL contexts. Bristol, UK: Multilingual Matters, 2019. p. 117-131.

HOLMES, P.; DERVIN, F. Introduction - English as a lingua franca and interculturality: Beyond orthodoxies. In HOLMES, P.; DERVIN, F. (Ed.). The cultural and intercultural dimensions of English as a Lingua Franca. Bristol, UK: Multilingual Matters, 2016. p. 1-30.

JENKINS, J. Repositioning English and multilingualism in English as a lingua franca. Englishes in Practice, v. 2, n. 3, p. 49-85, 2015.

JORDÃO, C. M. A língua inglesa como commodity: direito ou obrigação de todos? In ROMANOWSKY, J.; MARTINS, P.; JUNQUEIRA, S. (Org.). Conhecimento local e conhecimento universal. Curitiba: Champagnat, v. 3, 2004. p. 287-296.

JORDÃO, C. M.; MARQUES, A. N. English as a lingua franca and critical literacy in teacher education: Shaking off some "good old" habits. In GIMENEZ, T.; EL KADRI, M. S.; CALVO, L. C. S. (Ed.). English as a lingua franca in teacher education - A Brazilian perspective. Berlin: De Gruyter Mouton, 2018. p. 53-68.

KACHRU, B. B. Standards, codification and sociolinguistic realism: the English language in the outer circle. In QUIRK, R.; WIDDOWSON, H. (Ed.). English in the world: teaching and learning and literatures. Cambridge: Cambridge University Press, 1985. p. 11-30.

KEMALOGLU-ER, E.; BAYYURT, Y. ELF-awareness in teaching and teacher education: Explicit and implicit ways of integrating ELF into the English language classroom. In: SIFAKIS, N. C.; TSANTILA, N. (Ed.). English as a lingua franca for EFL contexts. Bristol, UK: Multilingual Matters, 2019. p. 159-174. .

KICZKOWIAK, M.; LOWE, R. Teaching English as a lingua franca - The Journey from EFL to ELF. Surrey, UK: Delta Publishing, 2018. 
KUBOTA, R. Inequalities of Englishes, English speakers, and languages: a critical perspective on pluralist approaches to English. In TUPAS, R. (Ed.). Unequal Englishes: the politics of Englishes today. New York: Palgrave Macmillan, 2015. p. 21-41.

LIMA, D. C. de. (Ed.). Inglês em escolas públicas não funciona? Uma questão, múltiplos olhares. São Paulo: Parábola, 2011.

LOPRIORE, L.; VETTOREL, P. Promoting awareness of Englishes and ELF in the English language classroom. In COGO, A.; BOWLES, H. (Ed.) International Perspectives on English as a Lingua Franca: Pedagogical Insights. New York: Palgrave Macmillan, 2015. p. 13-34.

MENEZES, V.; BRAGA, J.; CARNEIRO, M.; RACILAN, M.; GOMES, R.; VELLOSO, M. Alive High. São Paulo: Edições SM, 2013.

NAULT, D. Going global: Rethinking culture teaching in ELT contexts. Language, Culture and Curriculum, v. 19, n. 3, p. 314-328, 2006.

PENNYCOOK, A. Uma linguística aplicada transgressiva. In MOITA LOPES, L. P. da (Ed.). Por uma linguística aplicada indisciplinar. São Paulo: Parábola, 2006. p. 67-83.

PENNYCOOK, A.; OTSUJI, E. Metrolingual multitasking and spatial repertoires: 'Pizza mo two minutes coming'. Journal of Sociolinguistics, v. 18, n. 2, p. 161-184, 2014.

RAJAGOPALAN, K. The ambivalent role of English in Brazilian politics. World Englishes, v. 22, n. 2, p. 91-101, 2003.

RAJAGOPALAN, K. The concept of 'World English' and its implications for ELT. ELT Journal, v. 58, n. 2, p. 111-117, 2004.

SEIDLHOFER, B. Orientations in ELF research: form and function. In MAURANEN, A.; RANTA, E. (Eds.) English as a Lingua Franca: Studies and Findings. Newcastle upon Tyne, UK: Cambridge Scholars Publishing, 2009. p. 37-59.

SIFAKIS, N. C. ELF awareness as an opportunity for change: a transformative perspective for ESOL teacher education. Journal of English as a Lingua Franca, v. 3, n. 2, p. 317-335, 2014.

SIFAKIS, N. C. ELF awareness in English Language Teaching: Principles and processes. Applied Linguistics, v. 40, n. 2, p. 288-306, 2017.

SIFAKIS, N. C.; BAYYURT, Y. ELF-aware teaching, learning and teacher development. In JENKINS, J.; BAKER, W.; DEWEY, M. (Ed.). The Routledge Handbook of English as a lingua franca. London/New York: Routledge, 2018. p. 456-467. 
SIFAKIS, N. C.; TSANTILA, N. Introduction. In SIFAKIS, N. C.; TSANTILA, N. (Ed.). English as a lingua franca for EFL contexts. Bristol, UK: Multilingual Matters, 2019. p. 113.

SIQUEIRA, S. English language teaching and the place of culture: For a critical intercultural approach. In LIMA, D. C. de. (Ed.). Language and its culture substrate: Perspectives for a globalized world. Campinas, SP: Pontes, 2012. p. 193-216.

SIQUEIRA, S. English as a lingua franca and ELT materials: Is the "plastic world" really melting? In BAYYURT, Y.; AKCAN, S. (Ed.). Current perspectives on pedagogy for English as a lingua franca. Berlin: De Gruyter Mouton, 2015. p. 239-257.

SIQUEIRA, S.; MATOS, J. V. ELT materials for Basic Education in Brazil: Has the time for an ELF-aware practice arrived? In SIFAKIS, N. C.; TSANTILA, N. (Ed.). English as a Lingua Franca for EFL contexts. Bristol, UK: Multilingual Matters, 2019. p. 132-156.

TAVARES, K.; FRANCO, C. Way to Go! São Paulo: Editora Ática, 2013.

TÍLIO, R. O livro didático de inglês em uma abordagem sócio-discursiva - Culturas, identidades e pós-modernidade. Unpublished PhD Dissertation. Pontifícia Universidade Católica do Rio de Janeiro (PUC-Rio), RJ, Brazil, 2006.

TÍLIO, R.; ROCHA, C. H. As dimensões da linguagem em livros didáticos de inglês para o Ensino Fundamental I. Trabalhos em Linguística Aplicada, Campinas, v. 48, n. 2, p. 295-315, 2009. 
APPENDIX

The three Brazilian EFL Coursebooks analyzed

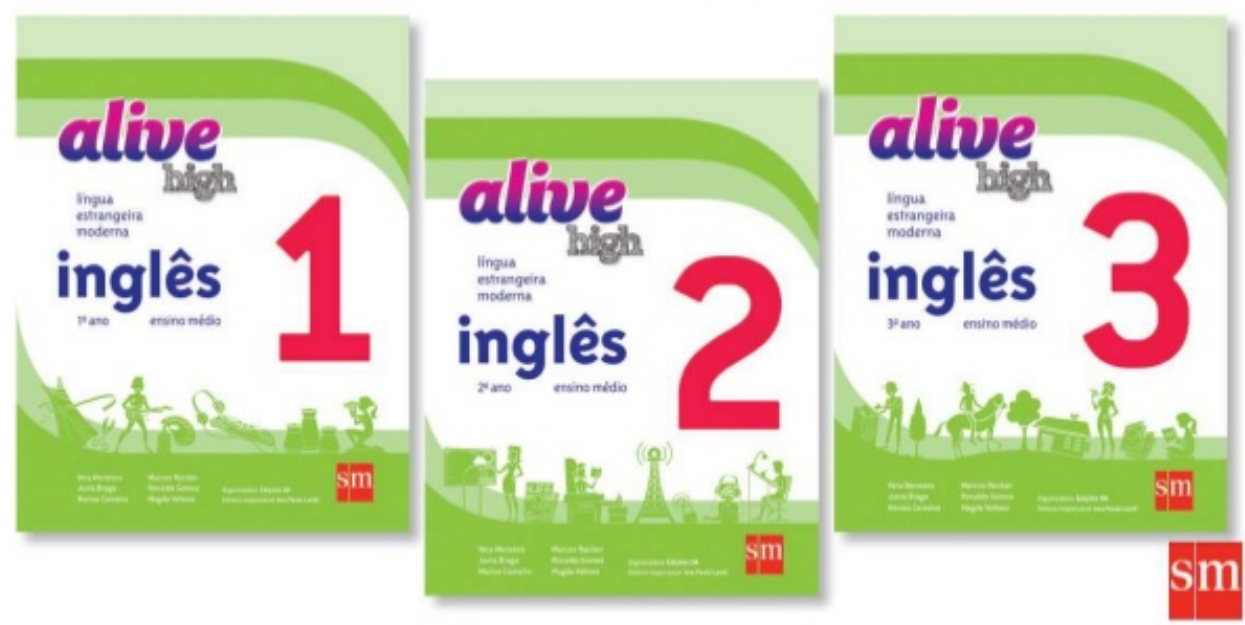

MENEZES, V.; BRAGA, J.; CARNEIRO, M.; RACILAN, M.; GOMES, R. \& VELLOSO, M. Alive High. São Paulo: Edições SM, 2013.

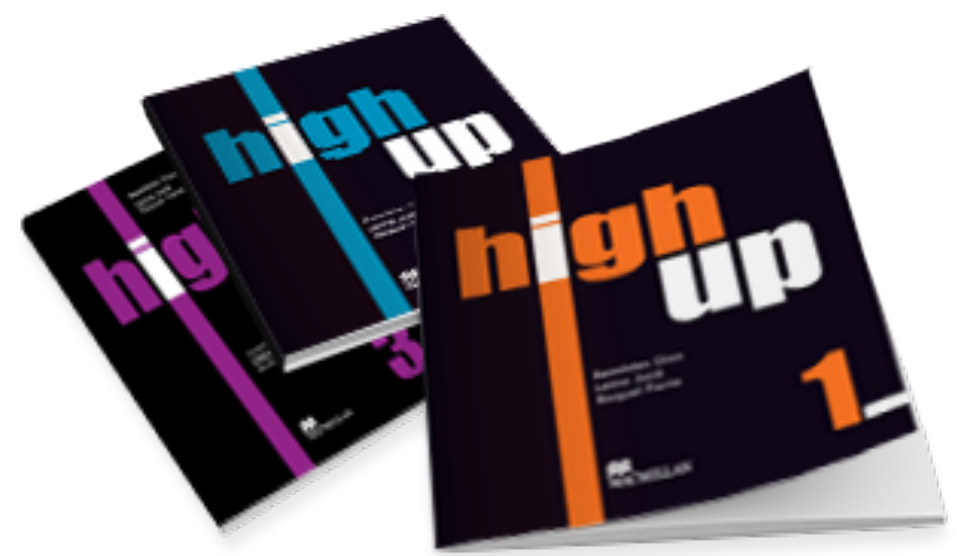

DIAS, R.; JUCÁ, L.; FARIA, R. High Up, São Paulo: Macmillan, 2013. 


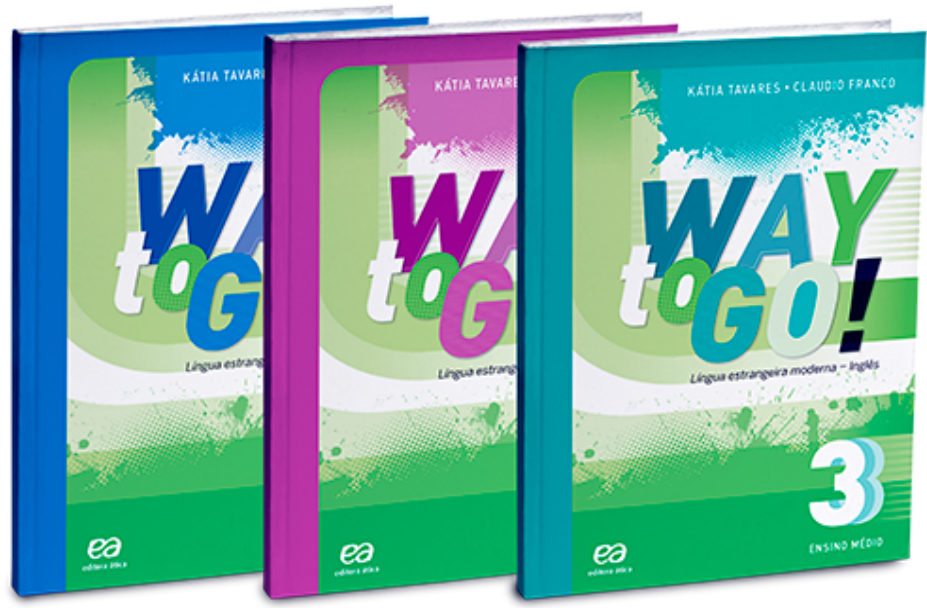

TAVARES, K.; FRANCO, C. Way to Go! São Paulo: Editora Ática, 2013.

\section{Sávio Siqueira}

Sávio Siqueira holds a PhD in Letters and Linguistics from Bahia Federal University (UFBA), Salvador, Brazil. He is an Associate Professor of English and Applied Linguistics at UFBA's Institute of Letters, also affiliated with the Post-Graduate Program in Language and Culture (UFBA) and the Post-Graduate Program in Letters at the Federal University of Tocantins (UFT). Dr. Siqueira has conducted postdoctorate studies on critical language pedagogy at the University of Hawai'i Manoa, Honolulu, HI, USA, and collaborates in the MA in Multiligualism, Linguistics and Education at Goldsmiths, University of London, UK. Having published extensively both in Brazil and abroad, he has recently co-edited Routledge's volume Refugees, Interculturalism and Education with Marco Catarci (Italy) and Miguel Gomes (Portugal). Among his research interests are ELF, World Englishes, Intercultural Education, Language Teacher Education, Decolonial studies, Critical Pedagogy, among others.

Nota do editor: Artigo submetido para avaliação em: 20/03/2019. Aprovado em sistema duplo cego em: 25/11/2019. 